\title{
Identifying environmental drivers of fungal non-pollen palynomorphs in the montane forest of the eastern Andean flank, Ecuador
}

\author{
Nicholas J.D. Loughlin ${ }^{\mathrm{a}, \mathrm{b}}$, William D. Gosling ${ }^{\mathrm{a}, \mathrm{b}}$, Encarni Montoya ${ }^{\mathrm{a}}$ \\ ${ }^{\mathrm{a}}$ School of Environment, Earth \& Ecosystem Sciences, The Open University, Walton Hall, Milton Keynes MK7 6AA, United Kingdom

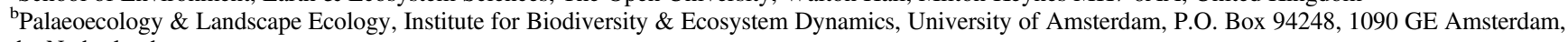 \\ the Netherlands
}

(Received January 30, 2017; AcCePted August 4, 2017)

\begin{abstract}
Samples taken from sedimentary archives indicate that fungal non-pollen palynomorphs (NPPs) can be used to provide information on forest cover, fire regime, and depositional environment in the eastern Andean flank montane forest of Ecuador. Within the 52 samples examined, 54 fungal NPP morphotypes are reported, of which 25 were found to be previously undescribed. Examination of fungal NPPs over a gradient of forest cover (2-64\%) revealed three distinct assemblages: (1) low $(<8 \%$ ) forest cover Neurospora, IBB-16, HdV-201, OU-102, and OU-110 indicative of an open degraded landscape; (2) medium (8-32\%) forest cover Cercophora-type 1, Xylariaceae, Rosellinia-type, Kretzschmaria deusta, Amphirosellinia, Sporormiella, and Glomus suggestive of a forested landscape disturbed by herbivores and soil erosion; and (3) high (32-63\%) forest cover Anthostomella fuegiana, OU-5, OU-101, OU-108, and OU-120. Environmental variables for forest cover (forest pollen), available moisture (aquatic remains), regional fire regime (microcharcoal), and sediment composition (organic carbon) were found to explain $\sim 40 \%$ of the variance in the fungal NPP data set. Fire was found to be the primary control on fungal NPP assemblage composition, with available moisture and sediment composition the next most important factors.
\end{abstract}

Keywords: Palaeoecology; Palaeoenvironment; Neotropics; Ecuador; Sample effect; Forest cover; Available moisture; Regional fire regime; Sediment composition; Depositional environment

\section{INTRODUCTION}

Estimates of global fungal diversity range from 1.5 to 5.1 million species (Blackwell, 2011; Hawksworth, 2012) with the greatest diversity found in tropical lowland and montane environments (Tedersoo et al., 2014). Fungi perform a vital function in terrestrial ecosystems as symbionts and decomposers of vegetation. Because of this role, a close relationship exists between plant and fungal communities (Hooper et al., 2000; Peay et al., 2013). Environmental drivers, including climate, fire regime, edaphic factors, and spatial distribution, play a role in fungal community composition (Tedersoo et al., 2014). The link between fungal community and environment allows fungal remains (ascospores, conidia, and chlamydospores) preserved in sedimentary archives to be used as a proxy in reconstructing palaeoenvironments (van Geel, 1972).

*Corresponding author at: School of Environment, Earth \& Ecosystem Sciences, The Open University, Walton Hall, Milton Keynes MK7 6AA, United Kingdom. E-mail address: nicholas.loughlin@open.ac.uk (N.J.D. Loughlin).
Non-pollen palynomorphs (NPPs), which include fungal remains, zoological remains, plant fragments, and algae, were first utilised to complement fossil pollen in reconstructing palaeoenvironmental records from northern European peat bogs (van Geel, 1972, 1976, 1978; van Geel et al., 1981, 1983; Kuhry, 1985). Combining NPPs with fossil pollen records has allowed new insight into past ecosystem functions to be gained and, consequently, has resulted in a more complete understanding of how, and why, ecosystems develop and change through time. Fungal NPPs have been used successfully to establish past trends of anthropogenic impact (van Geel et al., 2003; López-Sáez and López-Merino, 2007; Williams et al., 2011) and to provide evidence of herbivore extinctions (Davis, 1987; Gill et al., 2009, 2013), the role of herbivores in shaping landscapes (Davis and Shafer, 2006; Raper and Bush, 2009; Baker et al., 2013, 2016), and past mammalian behaviour (van Geel et al., 2008, 2011b). Despite the ability of fungal NPPs to provide unique complementary information on past environments, their use in the Neotropics has been limited because of a 
paucity of studies (Montoya et al., 2012), and within the Andes, their use is restricted to Venezuela (Rull and Vegas-Vilarrúbia, 1998, 1999; Rull et al., 2008; Montoya et al., 2010, 2012) and Colombia (Hooghiemstra, 1984; Kuhry, 1988; Grabandt, 1990).

The generally diverse nature of ecosystems and landscapes in the tropics has long been discussed (Wallace, 1878; MacArthur, 1969; Connell, 1978; Stevens, 1989) and has led to the tropical Andean region being identified as containing some of the most biodiverse ecosystems on the planet (Myers et al., 2000). Within the Andean biodiversity hot spot, the increase in species diversity within midelevation Andean tropical forests has been the focus of particular attention (Terborgh, 1977; Graham, 1983; Gentry, 1988). The reason for high biodiversity in the Andes has been variously attributed to the region's heterogeneous nature, dynamic environment, and high precipitation (Killeen et al., 2007; Hoorn et al., 2010). However, questions remain unanswered about the long-term ecological and environmental processes operating within these biodiverse Andean forests. The development of fungal NPPs as a proxy within the eastern Andean montane forest provides an opportunity to extract a new type of information on long-term ecological and environmental states and processes from the fossil record.

Recently, modern assemblage-environment calibration data sets for two biological proxies have been constructed for the Andes region: (1) pollen (Rull, 2006; Moscol-Olivera et al., 2009; Flantua et al., 2015) and (2) chironomids (Matthews-Bird et al., 2016a, 2016b). These quantitative methodologies use modern assemblage data and environmental variables to develop transfer functions with the aim of reconstructing past climatic conditions (Juggins and Birks, 2012). The modern calibration approach could be adapted to qualitatively investigate the autoecology of fungal NPPs along environmental gradients to provide new insight into the principal environmental controls governing specific fungal morphotypes. However, equivalent studies on the eastern Andean flank are hindered by the dynamic nature of the landscape, which limits the number of suitable locations (e.g., lakes, swamps, and bogs) within midelevation montane forests from which proxies, including fungal remains, can be recovered. Alternative sources of samples, such as surface soil and moss polsters, have been variously used to characterise the fungal NPPs of modern environments (Montoya et al., 2010). However, comparisons of NPP assemblages between different sample types (e.g., lake sediments vs. soil samples) is not optimal because of large differences induced by the local signal and limited dispersal potential of many fungal remains (i.e., a strong "sample effect") (Wilmshurst and McGlone, 2005; Montoya et al., 2010).

To overcome the challenge presented by an absence of suitable depositional environments from which to recover a modern calibration data set for NPPs, we have developed an alternative approach that relates fungal NPP assemblages to independent environmental proxies in sedimentary archives. In this article, we use palaeoenvironmental proxies of forest cover (forest pollen), available moisture (aquatic remains), regional fire regime (microcharcoal), and sediment composition (organic carbon) to provide environmental gradients against which to constrain the autoecological characteristics of fungal NPPs. Using sedimentary archives as a training data set allows us to explore assemblage shifts along longer environmental gradients than would be possible using just modern samples in the Andes. Through using the sedimentary archives, we significantly increase the number of samples from the optimal depositional environments (lakes, swamps, and bogs) and reduce the "sample effect" that can bias comparison with the fossil record. Furthermore, using sedimentary archives prior to, and after, the arrival of humans to the continent allows us to explore how fungal NPP assemblages developed in landscapes without the influence of people. Our novel approach will allow additional information about ecological and environmental processes to be incorporated into future palaeoenvironmental studies.

\section{THE EASTERN ANDEAN FLANK (ECUADOR)}

\section{Landscape}

The changing topography of the eastern Andean flank is the principal variable controlling vegetation composition and regulating air temperature, precipitation, and cloud cover (Harling, 1979; Graham, 2009). Uplift of the Andes began during the Miocene, with the collision of the Nazca and South American plates (Allmendinger et al., 1997), followed by accelerated uplift and widespread volcanic activity during the late Pliocene to early Pleistocene (Coltorti and Ollier, 2000). Throughout the Holocene, Ecuador has experienced a high degree of volcanism with at least 20 active volcanos (Hall et al., 2008). This complex geologic history has produced a variety of source rocks that give rise to the diverse range of soil compositions found within the Andes (Neill, 1999a; Vera, 2013).

\section{Vegetation}

Andean montane forests are composed of a narrow band $(\sim 30 \mathrm{~km})$ of tropical vegetation covering an altitudinal range of $2300 \mathrm{~m}$ (1300-3600 metres above sea level [m asl]) (Neill, 1999b). Montane forests can be split into three vegetation communities: lower montane forest $(1300-2000 \mathrm{~m}$ asl), cloud forest (2000-2900 $\mathrm{m}$ asl), and upper montane forest (2900-3600 m asl) (Sierra, 1999). Today, the study areas fall within the cloud forest type vegetation community (Fig. 1). The cloud forest in this region is composed of a mix of Andean and lowland forest elements including Alnus (Betulaceae), Arecaceae, Fabaceae, Hedyosmum (Chloranthaceae), Lauraceae, Melastomataceae, Meliaceae, Moraceae, Rubiaceae, Solanaceae, and Weinmannia (Cunoniaceae) (Harling, 1979; Gentry, 1995; Neill and Palacios, 1997; Neill, 1999b; Valencia et al., 1999). Forest canopy within the cloud forest reaches $15-25 \mathrm{~m}$, and trees are covered by abundant epiphytes including mosses, lichens, ferns, Bromeliaceae, Araceae, and Orchidaceae (Webster, 1995; Neill and Palacios, 1997). Human impact and forest clearance 


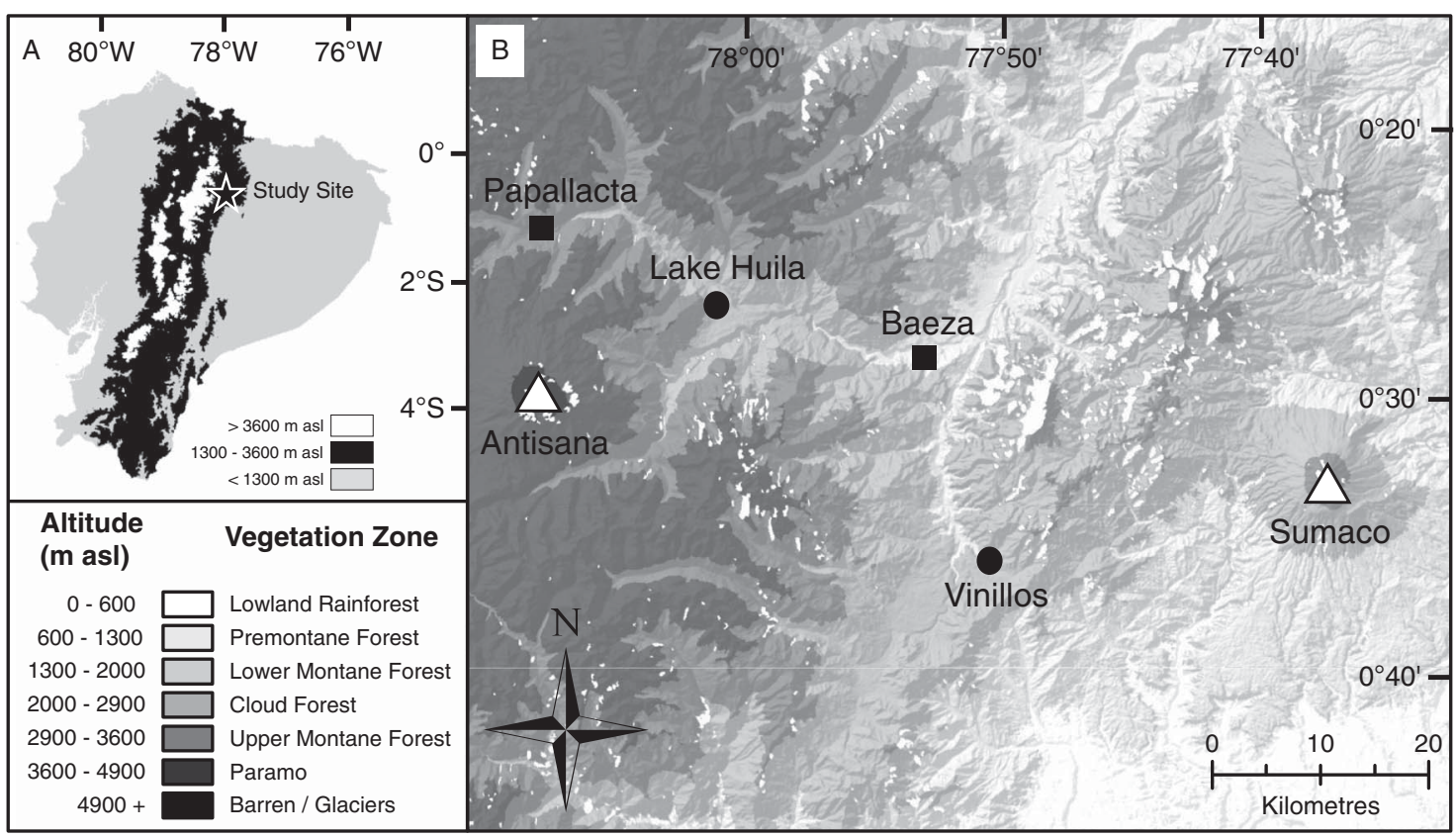

Figure 1. Map showing position of study site and sample locations. (A) Map of Ecuador. Regions coloured black indicate an altitude of between 1300 and 3600 metres above sea level (m asl) corresponding to Andean montane forest vegetation. (B) Map of study location with altitudinal gradient related to vegetation zones as described in the "Introduction" and corresponding to Sierra (1999). Circles indicate sample locations; squares, local population centres; and triangles, volcanic centres.

within the cloud forest occurs primarily near the river valley floor. Human activity and deforestation is characterised in the vegetation by an increase in herbaceous taxa, disturbance indicators such as Cecropia (Urticaceae) and large patches of pioneers such as Chusquea (Poaceae) and Gunnera (Gunneraceae), which also occur on steep-sided slopes following frequent landslides (Stern, 1995).

\section{Climate}

Precipitation on the eastern Andean flank is principally controlled by the South American summer monsoon (Vuille et al., 2000; Cook, 2009). Mean annual precipitation varies with altitude, with approximately $2500 \mathrm{~mm}$ of rainfall per year at $2000 \mathrm{~m}$ asl (Neill and Jørgensen, 1999). High levels of orographic rainfall and semipermanent ground-level clouds lead to reduced seasonality and persistent moist conditions (Harling, 1979). Mean annual temperature ranges from $16-20^{\circ} \mathrm{C}$ at approximately $2000 \mathrm{~m}$ asl (Galeas and Guevara, 2012), with an adiabatic lapse rate of $\sim 0.56^{\circ} \mathrm{C}$ per $100 \mathrm{~m}$ (Bush et al., 2004). Temperatures remain stable throughout the year; however, diurnal changes in temperature of up to $20^{\circ} \mathrm{C}$ can occur at higher elevations, acting as a much more significant control on vegetation distribution than seasonal changes in temperature (Neill and Jørgensen, 1999).

\section{STUDY SITES AND SAMPLES}

The study area is situated in the Quijos Canton in the Napo Province of Ecuador near the town of Baeza (Fig. 1). Two sedimentary archives were recovered from Lake Huila (hereafter referred to as Huila) and an exposed cliff section near the town of Cosanga (hereafter referred to as Vinillos). The Huila and Vinillos sediments were selected for development of a fungal NPP training data set because they allowed the fungal NPP assemblages to be constrained against environmental variables when humans were present (Huila), and absent (Vinillos), from the landscape-that is, the sites are securely radiocarbon dated to before, and after, the arrival of humans in South America ca. 12,000 yr ago (Rademaker et al., 2014).

\section{Huila}

Huila $\left(00^{\circ} 25.39^{\prime} \mathrm{S}, 78^{\circ} 01.06^{\prime} \mathrm{W}\right)$ is situated at $2608 \mathrm{~m}$ asl on a raised plateau adjacent to the Río Quijos (Fig. 1). The lake consists of a shallow $(\sim 1.10 \mathrm{~m}$ deep $)$ body of water approximately $800 \mathrm{~m}^{2}$, within a $\sim 4000 \mathrm{~m}^{2}$ closed basin, with no obvious inflow. The lake is situated in a cleared pasture used for cattle and horse grazing. The catchment is dominated by Poaceae and Cyperaceae, with the surrounding region consisting primarily of pastures and secondary forest. In 2013, a $2.11 \mathrm{~m}$ sediment core was recovered from the centre of the lake from a floating platform using a ColinvauxVohnout modified Livingstone piston corer (Livingstone, 1955; Colinvaux et al., 1999). Once recovered, the cores were returned to the Open University laboratory intact for storage in a cold room $\left(\sim 4^{\circ} \mathrm{C}\right)$. Radiocarbon dating has shown that the Huila sediments sampled (upper $49 \mathrm{~cm}$ ) were deposited during the last millennium (Table 1).

\section{Vinillos}

The Vinillos section $\left(00^{\circ} 36.04^{\prime} \mathrm{S}, 77^{\circ} 50.81^{\prime} \mathrm{W}\right)$ is located at $2090 \mathrm{~m}$ asl, approximately $3 \mathrm{~km}$ southeast of the town of 
Table 1. Radiocarbon (accelerator mass spectrometry) ages obtained from palynomorph residues from Huila and Vinillos. The dated sample from Huila is from the base of the sediment analysed (i.e., all the samples presented here are younger than the age of this sample). The dated sample from Vinillos is from the upper part of the sedimentary section (i.e.,, all the samples presented here are older than the age indicated). Original dates calibrated in OxCal 4.2.4 (Bronk Ramsey et al., 2013) using IntCal13 atmospheric curve (Reimer et al., 2013).

\begin{tabular}{llccc}
\hline \hline Study site & Laboratory code & $\begin{array}{c}\text { Radiocarbon } \\
\text { age }(\mathrm{yr} \mathrm{BP} \pm 1 \sigma)\end{array}$ & $\begin{array}{c}\text { Calibrated radiocarbon } \\
\text { age range 2 } \sigma(\mathrm{yr} \mathrm{BP})\end{array}$ & $\begin{array}{c}\text { Median calibrated } \\
\text { radiocarbon age (yr BP) }\end{array}$ \\
\hline Huila & D-AMS 017471 & $1052 \pm 27$ & $971-932$ & 956 \\
Vinillos & SUERC-58952 & $38,503 \pm 968$ & $43,325-41,885$ & 42,670 \\
\hline \hline
\end{tabular}

Cosanga (Fig. 1). The Vinillos section consists of an outcrop of exposed sediment revealed during the construction of the Troncal Amazónica (E45), a road running parallel to the Río Cosanga. Vinillos is today situated at the boundary between the lower montane forest and cloud forest, with vegetation at the site dominated by disturbance indicators (Cecropia, Gunnera, and Chusquea). In 2012, 50 discrete sediment samples were taken systematically through the dark-brown organic beds at $5 \mathrm{~cm}$ intervals along with individual bulk samples from four volcanic tephra layers. Samples were placed in ziplock bags and transported to the Open University to be stored in a cold room $\left(\sim 4^{\circ} \mathrm{C}\right)$. Lithologic information was recorded from individual samples in the laboratory. Radiocarbon dating indicates that the Vinillos sediments were deposited prior to ca. 42,000 yr ago (Table 1).

\section{METHODS}

A total of 52 samples were examined for fungal NPP remains selected from the two sedimentary archives: Huila (26 samples, designated sample codes starting with " $\mathrm{H}$ ") and Vinillos (26 samples, designated sample codes starting with "V"). Four independent proxies were also investigated in order to determine specific environmental variables. Three environmental data sets were obtained from the same samples as the NPP assemblages: (1) forest pollen (forest cover), (2) aquatic remains (available moisture), and (3) microcharcoal (regional fire regime). One data set was obtained from additional, equivalent, samples: organic carbon (sediment composition).

\section{Fungal non-pollen palynomorphs}

Samples were processed using standard protocols and included the addition of an exotic marker for the calculation of concentrations (Stockmarr, 1971): University of Lund, Lycopodium tablet batch \#124961 containing an average of $12,542 \pm 931$ spores per tablet. Sediment samples of $1 \mathrm{~cm}^{3}$ were sieved at $180 \mu \mathrm{m}$ and processed using $\mathrm{KOH}, \mathrm{HCl}, \mathrm{HF}$, and acetolysis (Faegri and Iversen, 1989; Moore et al., 1991). Eleven samples containing high levels of silica (V90, V160, V210, V250, and H31 to 49) were resampled and processed using density separation (Bromoform; 2 mol) instead of HF to improve visibility of palynomorphs. Previous studies indicate that samples processed using $\mathrm{HF}$ and density separation are directly comparable (Campbell et al., 2016). All sample residues were mounted on glass slides in glycerol and counted on a Nikon Eclipse 50i microscope at 400x and 1000x magnification. NPP remains were counted in conjunction with fossil pollen and are expressed as a percentage relative to the total terrestrial pollen sum - that is, any taxa with a potential aquatic affinity, such as Cyperaceae and Myriophyllum, are excluded from the terrestrial pollen sum. NPPs were counted until a minimum of 300 terrestrial pollen grains had been counted. Deviation from this methodology occurred in sample V5 where fungal spore type HdV-123 was overrepresented, accounting for $698.3 \%$ of the pollen sum; here the NPP count was increased until a minimum of 100 non-HdV-123 fungal spores had been counted. Identification of NPPs was undertaken using the available literature (van Geel, 1978; van Geel et al., 1981, 1983, 1989, 2003, 2011a; Bakker and van Smeerdijk, 1982; Hooghiemstra, 1984; van Smeerdijk, 1989; Rull and Vegas-Vilarrúbia, 1999; van Geel and Aptroot, 2006; Rull et al., 2008; Cugny et al., 2010; Montoya et al., 2010, 2012; Gelorini et al., 2011; López-Vila et al., 2014), types were recorded, and their known ecological affinities were described (Supplementary Appendix A). New NPP morphotypes encountered were assigned a unique code with the designation OU (The Open University), and their morphological characteristics were described based on a minimum of five examples (Supplementary Appendix B). New morphotypes, where fewer than five examples could be found, were not described or included in the diagrams.

\section{Environmental variables}

Four environmental variables were parameterised using independent proxies: (1) forest cover (forest pollen), (2) available moisture (aquatic remains), (3) regional fire regime (microcharcoal), and (4) sediment composition (organic carbon).

From the complete terrestrial fossil pollen data sets, four pollen types (Alnus, Weinmannia, Hedyosmum, and Melastomataceae) were selected as representatives of an Andean cloud forest vegetation community based on their occurrence in (1) modern vegetation surveys (Gentry, 1995; Jørgensen and León-Yánez, 1999), (2) modern pollen rain (Weng et al., 2004; Rull, 2006; Cárdenas et al., 2014), and (3) late Quaternary sedimentary archives (Hooghiemstra and van der 
Hammen, 1993; Colinvaux et al., 1997; Urrego et al., 2005; Niemann and Behling, 2008; González-Carranza et al., 2012; Cárdenas et al., 2014). This group of Andean cloud forest pollen taxa is referred to collectively from here on as "forest pollen."

Aquatic remains consisting of pollen and spores of aquatic taxa (Cyperaceae, Myriophyllum, and Isoetes), algae (Botryococcus, Spirogyra, Concentricystis, Mougeotia, Zygnema, Debarya, HdV-166B, and $\mathrm{HdV}-333$ ), and the remains of aquatic organisms (Chironomidae head capsules, HdV-179 and $\mathrm{HdV}-353 \mathrm{~B}$ ) were counted in conjunction with the terrestrial pollen. All aquatic remains were combined and expressed as a percentage relative to the total terrestrial pollen sum to provide information on the available moisture.

The presence of microcharcoal on the palynomorph slides was used to identify periods of regional fire activity (Whitlock and Larsen, 2001). Samples were examined for microscopic charcoal fragments $(5-100 \mu \mathrm{m})$ using a microscope at 200× magnification. Counts were then expressed as concentration of particles per cubic centimeter (Whitlock and Larsen, 2001).

Sediment samples of $\sim 2 \mathrm{~cm}^{3}$ were taken and processed for loss-on-ignition analysis at depths corresponding to the palynomorph and charcoal samples. Sediment was dried at $40^{\circ} \mathrm{C}$ for up to 5 days to remove moisture, followed by a controlled burn at $550^{\circ} \mathrm{C}$ for 4 hours to remove organic carbon (Heiri et al., 2001). Weight loss was then converted to a percentage of the dry weight to determine the proportion of organic carbon within the sediment.

\section{Zonation}

Samples were first ordered sequentially based on the percentage of forest pollen representatives from the sample (i.e., along an environmental gradient of forest cover) (Fig. 2). Zonation was based on NPP percentage abundance data of all morphotypes that occur in more than one sample and with an abundance of $>2 \%$ in at least one sample. Zones were then established using "optimal splitting by information content" (OSIC) using the program psimpoll (Bennett, 2008), and the statistical significance of zones was tested using the broken stick method (Bennett, 1996; Fig. 3). All data were plotted using the programme C2 (Juggins, 2007).

\section{Data analysis}

Canonical correspondence analysis (CCA) (ter Braak, 1986) was performed to investigate the influence of environmental variables (forest cover, available moisture, regional fire regime, and sediment composition) on the distribution of fungal NPPs. CCA analysis was performed on NPP percentage data after a square-root transformation had been applied. The purpose of the square-root transformation was to stabilise variance within the assemblages and compensate for the occurrence of overrepresented taxa that can occur with proxies that have a low dispersal potential, such as NPPs (Wilmshurst and McGlone, 2005). Within the CCA, fungal
NPP data were plotted against untransformed environmental data from forest pollen, aquatic remains, microcharcoal, and organic carbon (Fig. 4). Analysis of variance was used to test the significance of the variation in fungal NPPs explained by the environmental variables. CCA was performed in $\mathrm{R}$ ( $\mathrm{R}$ Development Core Team, 2015) using the package vegan (Oksanen et al., 2016).

\section{RESULTS}

\section{Fungal non-pollen palynomorphs}

A total of 52 samples were analysed, but 3 samples were determined to be barren of fungal NPPs (concentration $<2000$ spores per $\mathrm{cm}^{3}$ in samples V90, V135, and V160) and were consequently excluded from subsequent analysis. Analysis of fungal NPPs within the remaining 49 samples identified 54 distinct fungal morphological types, of which 51 met the requirements of the persistence ( $>1$ sample) and presence $(>2 \%$ abundance in one sample) filters. Twentynine morphotypes were assigned to previously described types and are recorded in Supplementary Appendix A along with pertinent ecological information. Twenty-five previously undescribed morphotypes were recorded, photographed (Fig. 5), and described in Supplementary Appendix B.

OSIC analysis of fungal NPP percentage data established three distinct zones that have been described based on their position along the forest cover environmental gradient: (1) low forest cover $(<8 \%$ forest pollen relative to terrestrial pollen sum), (2) medium forest cover (8-32\% forest pollen), and (3) high forest cover ( $>32 \%$ forest pollen). The boundary between the low forest cover and medium forest cover zones was found to be statistically significant based on the broken stick method (Fig. 3).

\section{Low forest cover zone (nine samples)}

Within the low forest cover zone, fungal NPP concentrations are low, with only two samples having greater than 10,000 spores per $\mathrm{cm}^{3}$ (H23 and H25). Samples are characterized by relatively high abundances of HdV-201 (0-18.6\%), IBB-16 (0-8.2\%), HdV-16A (0-5.5\%), OU-102 (0-7.5\%), and Neurospora $(0-2.2 \%)$. It is worth noting that morphotype OU-102 only occurs within the low forest cover zone and is present in six of the nine samples.

\section{Medium forest cover zone (22 samples)}

Within the medium forest cover zone, NPP concentrations fluctuate $\left(\sim 3400-570,000\right.$ spores per $\mathrm{cm}^{3}$; mean 180,000 spores per $\mathrm{cm}^{3}$ ), although it is worth noting that only 3 of the 22 samples $(\mathrm{H} 11, \mathrm{H} 21$, and H22) have high concentrations $\left(>500,000\right.$ per $\left.\mathrm{cm}^{3}\right)$. Samples are characterised by high abundances of Xylariaceae (0.3-100.6\%), Cercophoratype 1 (0-80.1\%), HdV-123 (0-698.3\%), HdV-495 (0-19.0\%), HdV-16A (0-54.6\%), and IBB-259 (0-12.9\%). It is also worth noting that OU-100 (0-12.4\%), and OU-104 $(0-4.3 \%)$ are most abundant within the medium forest zone. 


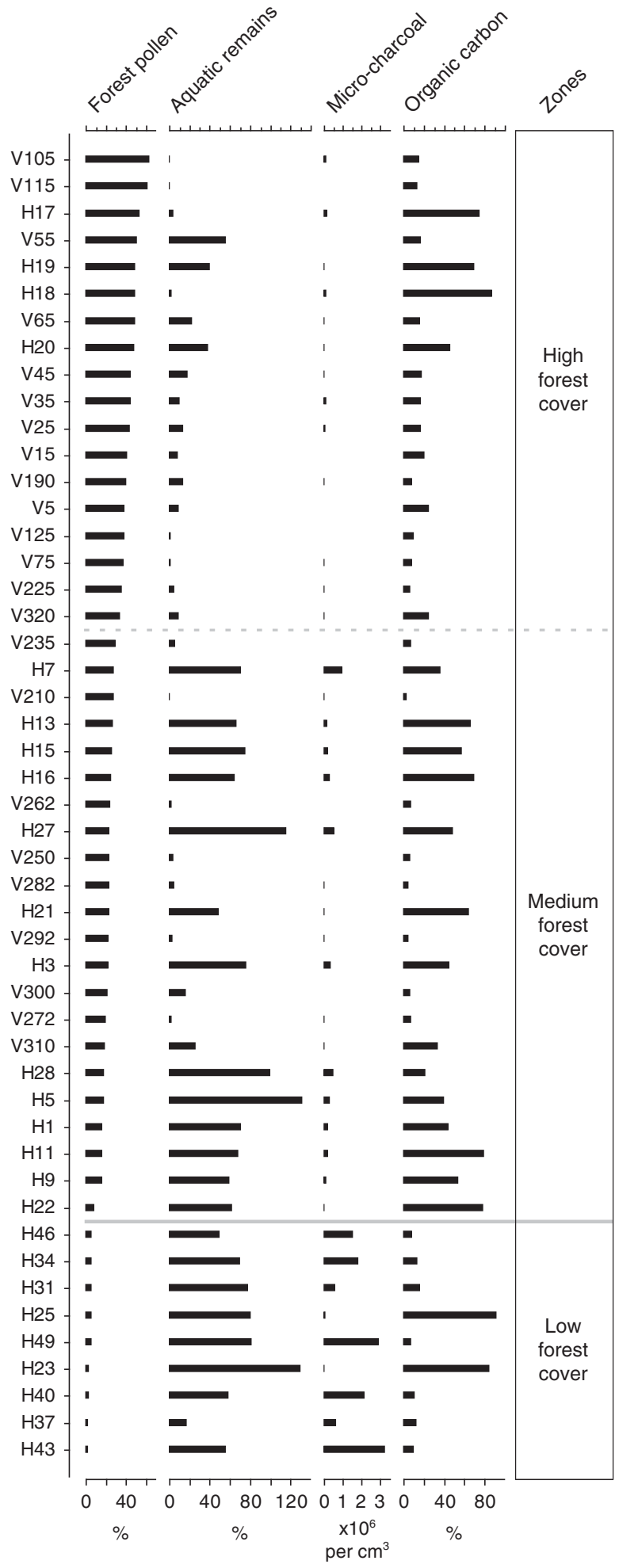

Figure 2. Palaeoenvironmental proxies from which environmental variables have been inferred. Samples are ordered based on increasing percentage of forest pollen. Forest pollen is based on the combined percentage of Alnus, Weinmannia, Hedyosmum, and Melastomataceae in the sample relative to the total terrestrial pollen sum. Aquatic remains relate to the percentage abundance of total aquatic remains relative to the terrestrial pollen sum. Microcharcoal plotted as fragments per cubic centimetre of sediment. Organic carbon refers to the percent organic carbon loss during loss on ignition at $550^{\circ} \mathrm{C}$.

\section{High forest cover (18 samples)}

Within the high forest cover zone, fungal NPP concentrations range from $\sim 10,000$ to $1,000,000$ spores per $\mathrm{cm}^{3}$. The most persistent and abundant fungal types include $\mathrm{HdV}-123$ (0-68.7\%), Xylariaceae (0.1-20.7\%), HdV-495 (0-11.4\%), and IBB-259 $(0.2-36.3 \%)$. It is also worth noting that OU-108 (0-75.3\%) is more abundant in the high forest cover zone than any other zone, and that it reaches exceptionally high abundances in one sample (V25).

\section{Environmental variables}

The four independent indicators of environmental gradients (forest pollen, aquatic remains, microcharcoal, and organic carbon) have been plotted against increasing forest pollen percentage data (Fig. 2). Forest pollen components (Alnus, Hedyosmum, Weinmannia, and Melastomataceae) occur over a gradient of $2.5-63.5 \%$ of the total terrestrial pollen sum. Aquatic remains in the low and medium forest cover zones fluctuate widely in abundance (low $=17-130 \%$ of the total terrestrial pollen sum, mean $69 \%$; medium $=0.5-131 \%$, mean $49 \%$ ), whereas aquatic remains in the high forest pollen zone have less variance $(0.8-56 \%)$ and a lower mean $(14.5 \%)$. Microcharcoal is most abundant within the zone of low forest cover where it occurs in concentrations of up to $\sim 3,300,000$ fragments per $\mathrm{cm}^{3}$ (sample H43). In the zones of medium and high forest cover, microcharcoal concentrations progressively decrease (medium $=<1,000,000$ fragments per $\mathrm{cm}^{3}$; high $=<200,000$ fragments per $\mathrm{cm}^{3}$ ). The organic content of the sediment varies along the entire forest cover gradient with similar mean values $(\mathrm{low}=29 \%$; medium $=$ $36 \%$; high $=28 \%$ ) and a range of $3.2-92.0 \%$ organic carbon.

\section{Canonical correspondence analysis}

CCA of the transformed fungal NPP data and the four environmental variables were plotted (Fig. 4). The explanatory (environmental) variables account for $40 \%$ (constrained inertia $=0.8187$ ) of the variance in the fungal NPP percentage data (total inertia $=2.0438$ ). The first two CCA axes account for $90 \%$ of the explained variance (eigenvalues: CCA $1=0.4235$; CCA $2=0.3198$ ). The closest relationship of an environmental variable and a CCA axis is found between the aquatic remains and the positive side of axis 2 . The length attained by microcharcoal points to a degree of affinity with the negative values of axis 1 . Forest pollen and organic carbon do not present a clear relationship with either of the axes based on the angles formed in the plot, but the direction of the trends suggests an inverse relationship between forest pollen and microcharcoal (Fig. 4).

Fungal NPPs cluster into three broad groups. Morphotypes such as Neurospora, HdV-201, and IBB-16 covary with the microcharcoal gradient. Anthostomella fuegiana, TM-211, and HdV-495 covary with the forest pollen gradient, and Podospora, Gaeumannomyces/Clasteropspriom caricinum, conidiophores, UG-1194, and IBB-25 covary with the aquatic 


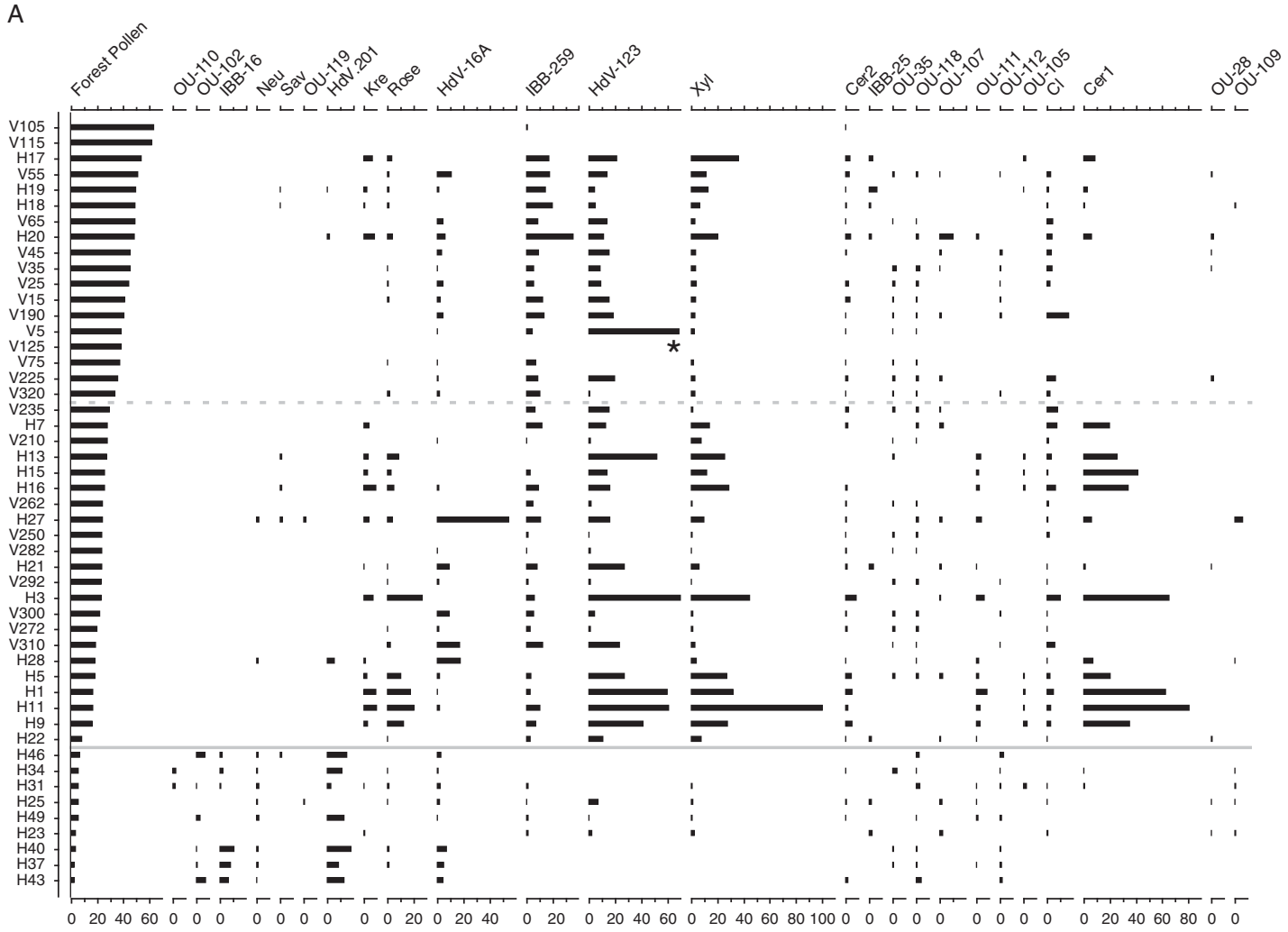

B

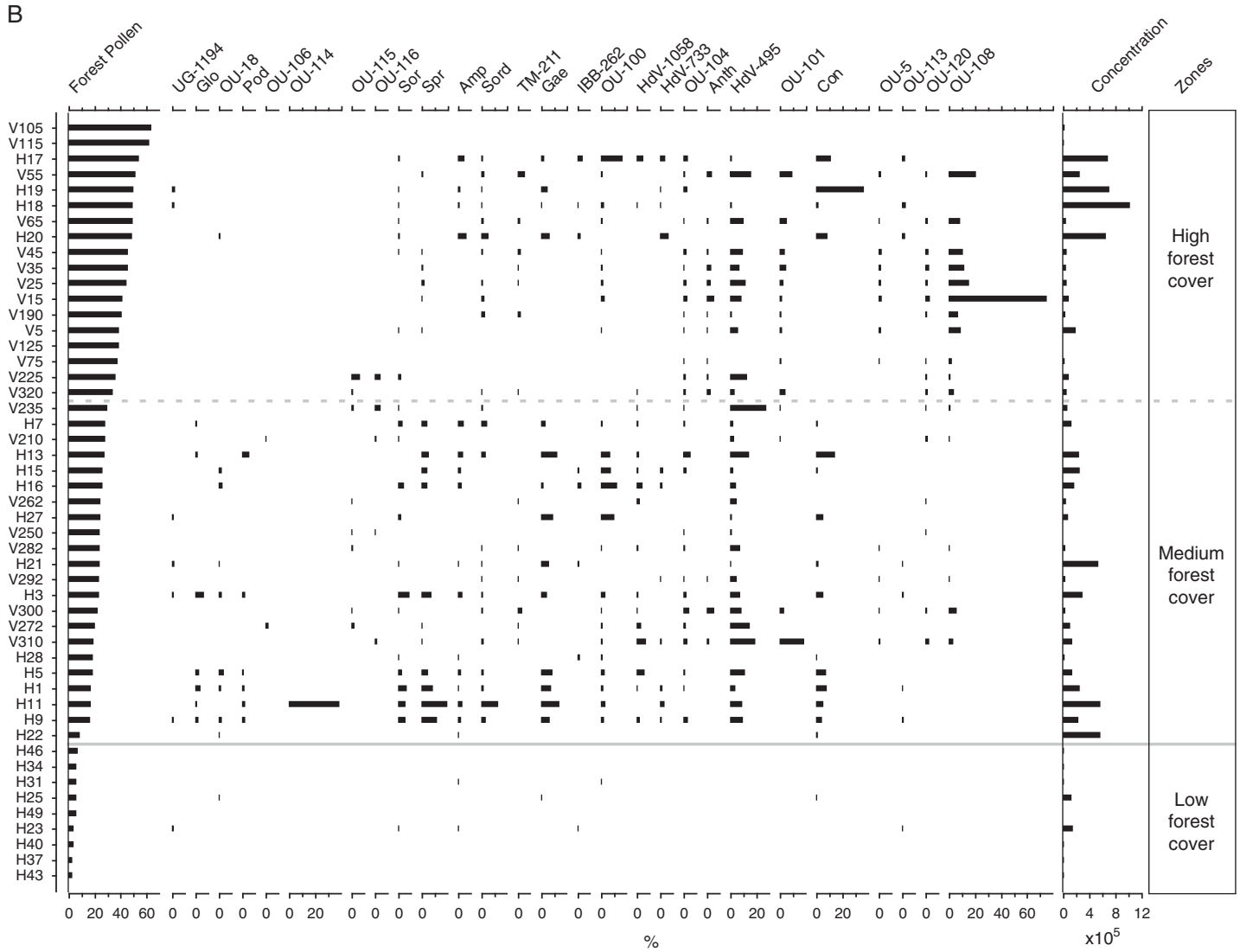

Figure 3. (A, B) Fungal non-pollen palynomorph (NPP) assemblage data for all taxa occurring at $>2 \%$ abundance in $>1$ sample. Fungal NPP percentages are calculated relative to the total terrestrial pollen sum. Samples are ordered based on an increasing percentage of forest pollen. Asterisk (*) in panel A indicates that HdV-123 in sample V5 occurs at $698.3 \%$. See Table 2 for definitions of abbreviations. 


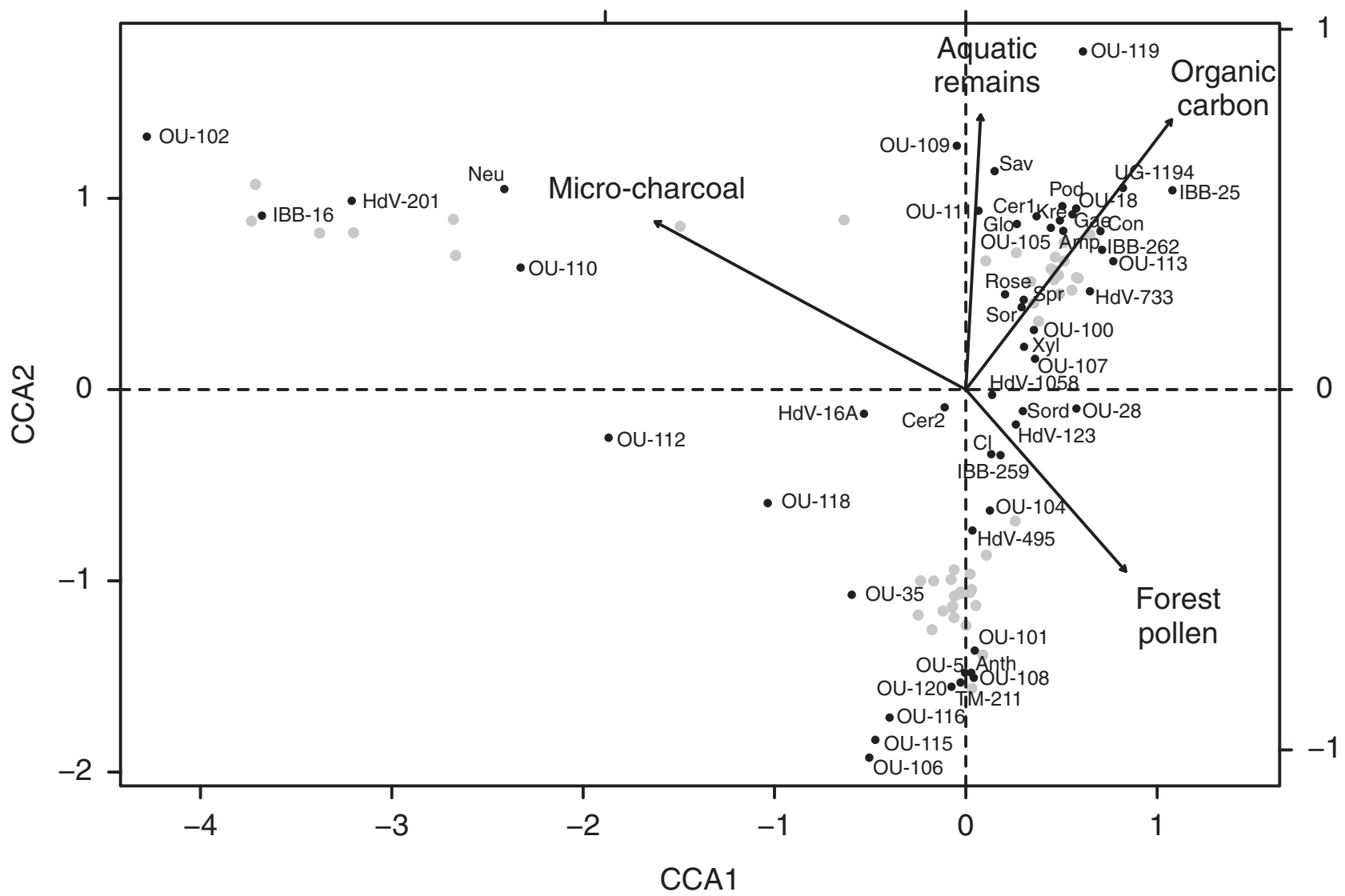

Figure 4. Canonical correspondence analysis (CCA) of non-pollen palynomorph (NPP) morphotypes and environmental variables. NPP morphotypes (black dots) and samples (grey dots) are plotted against palaeoenvironmental proxies of environmental variables (black arrows): forest pollen (forest cover), aquatic remains (available moisture), microcharcoal (regional fire regime), and organic carbon (sediment composition). See Table 2 for definitions of abbreviations.

remains and organic carbon gradients. Fungal NPPs that plot in the centre of the ordination are not strongly controlled by any one of the tested environmental variables (e.g., Cercophoratype 2 and $\mathrm{HdV}-1058$ ) or are ubiquitous throughout the samples (e.g., Xylariaceae-type and HdV-16A).

\section{DISCUSSION}

\section{Variance in fungal non-pollen palynomorphs along a gradient of forest cover in the Andes}

NPPs show a statistically significant variation along the forest cover gradient sampled (2.5-63.5\%; Fig. 3). The occurrence of distinct NPP taxa assemblages in the three forest cover zones suggests that NPP assemblages could be used as indicators of forest cover on the eastern Andean flank.

The NPP assemblage in the low forest cover zone is characterised by an abundance of HdV-201, IBB-16, Neurospora, and HdV-16A. Interestingly, the two samples that do not contain the most abundant NPP taxa in the low forest cover zone (HdV-201) are also unusual in that they have a sediment organic carbon $\sim 60 \%$ greater than any other sample (Fig. 2). The link between HdV-201 and organic carbon suggests that perhaps local factors that limit organic input into the sediment are important for HdV-201. The presence of the carbonicolous fungal NPP Neurospora within the low forest cover zone in conjunction with high microcharcoal indicate that regional and local fires likely occurred within areas of low forest cover. The high proportion of aquatic remains, here predominantly the semiaquatic pollen Cyperaceae, might suggest a marsh-type depositional environment. However, the low organic carbon content of the sediment indicates a low productivity environment. Additional fungal NPPs from the low forest pollen zone include types indicative of more open environments (Fig. 3). HdV-201 occurs on helophytes in drying pools (van Geel et al., 1989), and IBB-16 within páramo (high Andean grasslands) vegetation (Montoya et al., 2010). This combination of environmental conditions and fungal NPP morphotypes suggests an open depositional environment, with forest pollen input probably from extralocal sources. All samples from the low forest pollen zone belong to post-human arrival Huila sediments. The low abundance of forest pollen, low organic carbon content, and regional to local fire activity can be interpreted as indicative 
Table 2. Abbreviations of taxa used in non-pollen palynomorph diagram (Fig. 3) and canonical correspondence analysis diagram (Fig. 4).

\begin{tabular}{|c|c|c|}
\hline Identification & Morphotype & Abbreviation \\
\hline Amphirosellinia-type & Various & Amp \\
\hline Anthostomella fuegiana & $\mathrm{HdV}-4$ & Anth \\
\hline Cercophora-type 1 & $\mathrm{HdV}-112$ & Cer1 \\
\hline Cercophora-type 2 & HdV-1013 & Cer2 \\
\hline Conidiophores & HdV-96 & Con \\
\hline Coniochaeta $\mathrm{cf}$. ligniaria & $\mathrm{HdV}-172$ & $\mathrm{Cl}$ \\
\hline $\begin{array}{l}\text { Gaeumannomyces or Clasteropspriom } \\
\text { caricinum }\end{array}$ & $\mathrm{HdV}-126$ & Gae \\
\hline Glomus & $\mathrm{HdV}-207$ & Glo \\
\hline Kretzschmaria deusta & $\mathrm{HdV}-44$ & Kre \\
\hline Neurospora spp. & $\begin{array}{l}\text { HdV-1093; } \\
1351\end{array}$ & $\mathrm{Neu}$ \\
\hline Podospora-type & $\mathrm{HdV}-368$ & Pod \\
\hline Rosellinia-type & HdV-1058 & Rose \\
\hline Savoryella curvispora-type & HdV-715 & Sav \\
\hline Sporormiella-type & $\mathrm{HdV}-113$ & Spr \\
\hline Sordaria-type & $\mathrm{HdV}-55$ & Sor \\
\hline Sordariales & Various & Sord \\
\hline Xylariaceae-type & Various & Xyl \\
\hline N/A & $\mathrm{HdV}-16 \mathrm{~A}$ & $\mathrm{HdV}-16 \mathrm{~A}$ \\
\hline N/A & $\mathrm{HdV}-123$ & $\mathrm{HdV}-123$ \\
\hline N/A & HdV-201 & HdV-201 \\
\hline N/A & $\mathrm{HdV}-495$ & HdV-495 \\
\hline N/A & $\mathrm{HdV}-733$ & HdV-733 \\
\hline N/A & HdV-1058 & HdV-1058 \\
\hline N/A & TM-211 & TM-211 \\
\hline N/A & UG-1194 & UG-1194 \\
\hline N/A & IBB-16 & IBB-16 \\
\hline N/A & IBB-25 & IBB-25 \\
\hline N/A & IBB-259 & IBB-259 \\
\hline N/A & IBB-262 & IBB-262 \\
\hline
\end{tabular}

Note: N/A refers to NPP morphotypes with no know affinity.

of landscapes degraded by humans based on comparisons with similar findings in modern studies of managed areas elsewhere in the Andes (Rull, 2006; Moscol-Olivera et al., 2009).

The statistically significant zonation at $\sim 8 \%$ forest cover occurs where the NPP assemblage changes to one containing an increase of morphotypes associated with decaying plant remains and high-elevation grassland (páramo) (Fig. 3). The zone of medium forest cover contains ligneous and saprophytic morphotypes such as Cercophora-type 1, Xylariaceae, Rosellinia-type, Kretzschmaria deusta, Amphirosellinia, and Coniochaeta cf. ligniaria (van Geel et al., 2003; van Geel and Aptroot, 2006) indicative of an increase in woody taxa. Morphotypes HdV-123, HdV-495, HdV-733, and Gaeumannomyces/ Clasteropspriom caricinum previously identified in marshtype environments are also abundant (van Geel, 1978; van Geel et al., 1981; Bakker and van Smeerdijk, 1982). The occurrence of these types in conjunction with the mycorrhizal fungi Glomus, an indicator of increased basin erosion, and the coprophilous fungi Sporormiella and Podospora suggests that the medium forest cover zone has been subjected to a degree of disturbance by herbivores and basin erosion. The transition from the medium to high forest cover zone is not statistically significant; however, some changes in the NPP assemblage can be observed. In the medium forest cover zone, obligate coprophilous fungi (Sporormiella and Podospora) and occasional coprophilous fungi (Cercophoratype 1 and Sordaria-type) are all at their most abundant along the forest gradient, suggesting a relationship between herbivores and medium forest cover. Furthermore, in the high forest cover zone, Anthostomella fuegiana, an ascospore associated with the host plants Cyperaceae and Juncaceae (van Geel, 1978), and new morphotypes OU-5, OU-101, OU-108, and OU-120 are more prevalent than at any other point on the gradient. The reduction in microcharcoal associated with the zone of high forest cover and the loss or reduction in the carbonicolous fungal spore Neurospora, disturbance indicator Glomus, and coprophilous fungi suggest an environment with little evidence of disturbance. Therefore, our data suggest that the fungal NPP assemblage formed by Neurospora, HdV-201, IBB-16, OU-102, and OU-110 could be tentatively used as a proxy for open environments (or degraded lands) within the montane forests of the eastern Andean flank.

\section{Fungal NPP assemblages and environmental variables}

The variables tested in this study form three groups of fungal NPPs along environmental gradients related to regional fire regime (microcharcoal), depositional environment (organic carbon and aquatic remains), and forest cover (forest pollen) (Fig. 4). Together, fire, depositional environment, and forest cover explain $\sim 40 \%$ of the variance in the NPP data set, indicating that environmental variables not parameterised here (e.g., climate, human impact or disturbance, and plant-fungal interactions) have a strong influence on assemblage composition.

\section{Fire regime}

Five NPP morphotypes have been identified as covarying with regional fire regime (microcharcoal) on the eastern Andean flank (upper left portion of Fig. 4); of these, three have been previously described, and two are newly described in this study. Three previously described morphotypes that covary with regional fire regime are Neurospora, HdV-201, and IBB-16. Neurospora commonly occurs in the tropics on the surface of charred wood remains and is consequently seen as directly indicative of the presence of local fire events (Jacobson et al., 2006). In this study, the strong affinity of Neurospora with fire regime supports the interpretation of this NPP type with burning. The two other NPPs associated with fire in this study (HdV-201 and IBB-16) have been previously linked to helophyte remains in drier microhabitats (van Geel et al., 1989) and páramo 

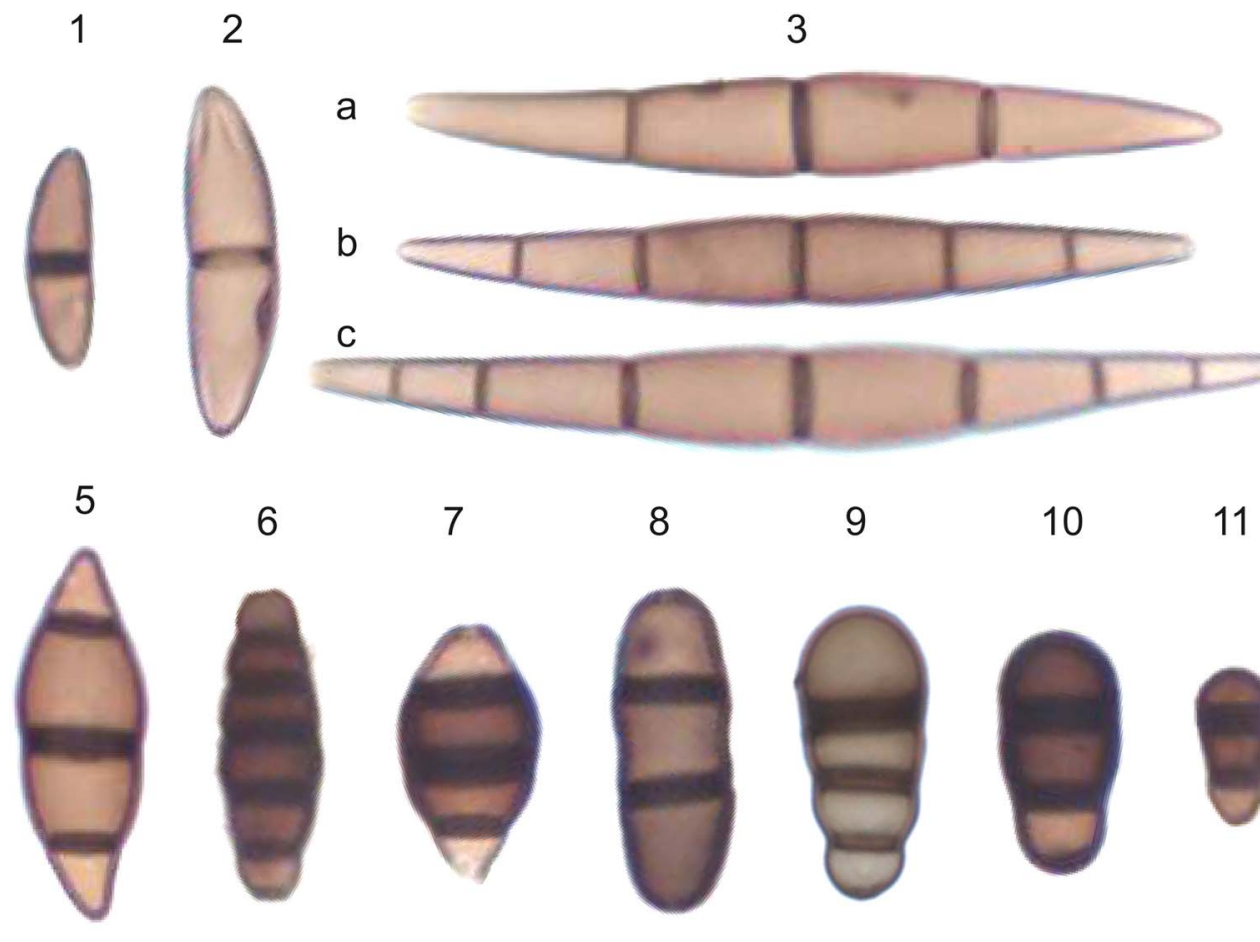

11
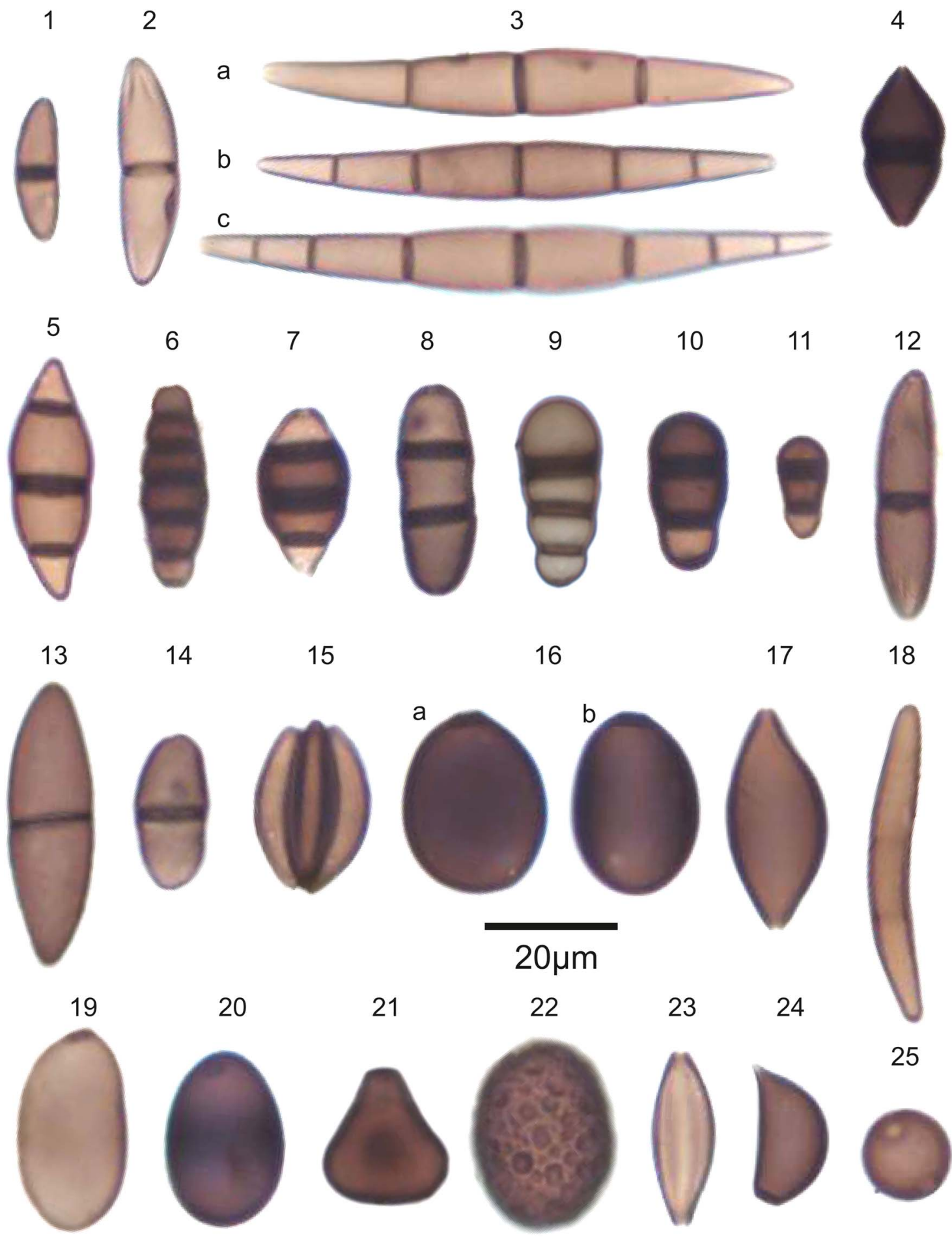

17

18

Figure 5. (colour online) New fungal morphotypes described from the eastern Andean flank of Ecuador. Conidia positioned with proximal cell at bottom. 1, OU-5; 2, OU-18; 3, OU-28 (a-c); 4, OU-35; 5, OU-100; 6, OU-101; 7, OU-102; 8, OU-103; 9, OU-104; 10, OU-105; 11, OU-106; 12, OU-107; 13, OU-108; 14, OU-109; 15, OU-110; 16, OU-111; 17, OU-112; 18, OU-113; 19, OU-114; 20, OU-115; 21, OU-116; 22, OU-117; 23, OU-118; 24, OU-119; 25, OU-120. 
environments (Montoya et al., 2010), respectively. The association between the sole carbonicolous fungal NPP (Neurospora) and morphotypes indicative of a more open habitat (HdV-201 and IBB-16) fits with the inverse relationship between the fire regime and forest cover gradients in the CCA analysis (Fig. 4). The newly described morphotypes adjacent to the microcharcoal gradient (OU-102 and OU-110) occur only within seven samples (H31 to H49), which contain seven of the eight highest concentrations of microcharcoal in the whole data set (Fig. 3). These seven samples also have low forest cover $(<8 \%)$ and organic content $(<17 \%)$. The fungal NPP assemblage of Neurospora, HdV-201, IBB-16, OU-102, and OU-110 is therefore suggested to be broadly indicative of elevated fire regimes and appears in semiopen environments, with poor or degraded soils.

\section{Depositional environment}

Aquatic remains (moisture availability) and organic carbon (sediment composition) covary with the greatest abundance of NPP morphotypes (upper right region of the ordination in Fig. 4). The taxa comprise a number of fungal NPP morphotypes with a variety of autoecological characteristics suggested to relate to the dynamic and heterogeneous nature of eastern Andean montane landscape. Morphotypes IBB-262 and IBB-25 have previously been identified from within the cloud forest and páramo environments of Colombia and Venezuela (Hooghiemstra, 1984; Montoya et al., 2010). Amphirosellinia sp. and Kretzschmaria deusta are parasitic tree fungi often associated with rotting wood (Ju et al., 2004; Innes et al., 2010). Kretzschmaria deusta occurs on common Andean montane forest taxa such as Alnus sp. and Ilex sp. (van Geel and Andersen, 1988), and increased abundance has been related to severe rainstorms during the Holocene (van Geel et al., 2013). Morphotype HdV-733 and Savoryella curvispora occur in mesotrophic marshes dominated by wetland grasses (Bakker and van Smeerdijk, 1982), of which Gaeumannomyces sp./ Clasteropspriom caricinum are the hyphopodium of leaf parasites on Cyperaceae. The coprophilous fungi Podospora and Sporormiella also occur along the organic carbon gradient suggesting a possible link between the presence of herbivores and increased organic carbon. The newly described morphotypes (OU-18, OU-105, OU-113, and OU-119) that occur in this region of the CCA are from samples that exhibit high organic content (41-75\%), but variable forest cover (3-54\%). Fungal NPP assemblages containing Cercophora-type 1, Amphirosellinia sp., Kretzschmaria deusta, Gaeumannomyces sp./Clasteropspriom caricinum, IBB-262, IBB-25, UG-1194, OU-18, OU-105, OU-113, and OU-119 are therefore suggested to be broadly indicative of organic-rich depositional environments; however, it is likely that multiple factors are responsible for the elevated organic levels (e.g., elevated sediment organic carbon content could result from high forest cover and/or the presence of herbivores).

\section{Forest cover}

The forest pollen gradient covaries closely with two previously identified NPP morphotypes (lower right region in Fig. 4). HdV-495 has been identified within the Andean montane forest and páramo of Venezuela (Montoya et al., 2010), and IBB-259 from within montane settings in Europe (López-Vila et al., 2014). The lack of NPP morphotypes closely associated with the forest pollen gradient indicates a weak relationship between forest cover and fungal NPP assemblage. The absence of a close relationship between forest cover and the overall NPP assemblage supports the findings of previous studies that NPPs provide a local signal (Wilmshurst and McGlone, 2005; Montoya et al., 2010).

It is interesting to note that the samples most closely aligned with high forest cover are from the prehuman Vinillos sediments and are associated primarily with new morphotypes OU-5, OU-101, OU-106, OU-108, OU-115, OU-116, and OU-120 (lower central region in Fig. 4). However, the lack of a clear association with our environmental variables suggests that unparameterised factors are primarily driving fungal NPP assemblages in the prehuman Andean landscape. Based on the data available, it could be suggested that the inverse relationship of these morphotypes with the gradients for aquatic remains and organic carbon may indicate that this unidentified gradient corresponds to other edaphic factors. The absence of NPP identifications and environmental association along the forest cover gradient illustrates that much research is still required in this area but suggests that further ecological information will be gleaned about prehuman Andean landscapes as the NPP record becomes better understood.

\section{CONCLUSIONS}

Here we present 54 distinct fungal NPP types identified from Quaternary sedimentary archives from the eastern Andean flank of Ecuador. This work represents the first record of fungal NPPs from Ecuador and identifies 25 new fungal NPP morphotypes (Supplementary Appendix B). Along an environmental gradient of forest cover, fungal NPPs show a statistically significant change between low and medium levels of forest cover. The NPP assemblage found in low forest cover is characterised by the morphotypes Neurospora, HdV-201, IBB-16, OU-102, and OU-110. Increases in forest cover above this point produce no statistically significant change in NPP assemblage composition. However, preliminary groups of morphotypes more common in medium and high forest cover include Cercophora-type 1, Xylariaceae, Rosellinia-type, Kretzschmaria deusta, Glomus, Podospora, Sporormiella, HdV-16A, and OU-18, and Anthostomella fuegiana, OU-5, OU-101, OU-108, and OU-120, respectively.

The comparison of fungal NPP assemblage data with independent environmental proxy data derived from 
sedimentary archives within a CCA has demonstrated that this method can be used to improve our understanding of NPP autoecology. This improved understanding of NPPs will, we hope, improve palaeoenvironmental reconstructions from the Andes. However, future work undertaking modern NPP altitudinal transects in conjunction with mycological field studies to understand plant-fungal interactions in these biodiverse forests are required in order to capitalise on the use of NPPs as an effective palaeoecological proxy in the Neotropics. Among the environmental variables considered, fire regime (microcharcoal) and depositional environment (aquatic remains and organic carbon) were found to be the most important explanatory variables. Moreover, the importance of fire occurrence has been related to the only statistically significant zone $(<8 \%$ forest cover) found, which is characterised by the fungal NPP assemblage Neurospora, HdV-201, IBB-16, OU-102, and OU-110, representing an open and degraded landscape within the montane forests of the eastern Andean flank that only occurs subsequent to human arrival on the continent. Further studies of modern and sedimentary samples along a variety of environmental gradients are required to improve the utility of fungal NPPs as a proxy within the Andes. To progress understanding of NPPs in the Andes, we recommend that all NPP remains should be recorded as part of any palynological investigation, even when the identities of the NPP morphotypes are unknown.

\section{ACKNOWLEDGMENTS}

This work was supported by the Natural Environment Research Council (NERC) and the Open University through a scholarship to NJDL (NE/L501888/1), and an NERC fellowship to EM (NE/J018562/1). Radiocarbon dating was funded by the NERC radiocarbon committee (\#1810.0414) and undertaken by Pauline Gulliver at the NERC Radiocarbon Facility East Kilbride (NRCF010001). The Huila (2013) fieldwork was undertaken as part of an NERC fellowship (NE/J018562/1). The Vinillos (2012) fieldwork was undertaken as part of an NERC-funded studentship (NE/J500288/1). We thank Annemarie Philip (University of Amsterdam, the Netherlands) for assistance with palynomorph preparation, Patricia Mothes (Instituto Geofísico, Escuela Politécnica Nacional, Ecuador) for guiding us to the Vinillos and Huila sites, and Hayley Keen, Frazer Matthews-Bird, and James Malley (all from the Open University, United Kingdom) for assisting with the collection of the Vinillos samples. The authors wish to especially thank Bas van Geel and an anonymous reviewer for their comments and constructive criticism of the manuscript.

\section{SUPPLEMENTARY MATERIAL}

To view supplementary material for this article, please visit https://doi.org/10.1017/qua.2017.73

\section{REFERECES}

Allmendinger, R.W., Jordan, T.E., Kay, S.M., Isacks, B.L., 1997. The evolution of the Altiplano-Puna Plateau of the central Andes. Annual Review of Earth and Planetary Sciences 25, 139-174.
Baker, A.G., Bhagwat, S.A., Willis, K.J., 2013. Do dung fungal spores make a good proxy for past distribution of large herbivores? Quaternary Science Reviews 62, 21-31.

Baker, A.G., Cornelissen, P., Bhagwat, S.A., Vera, F.W.M., Willis, K.J., 2016. Quantification of population sizes of large herbivores and their long-term functional role in ecosystems using dung fungal spores. Methods in Ecology and Evolution 7, 1273-1281.

Bakker, M., van Smeerdijk, D.G., 1982. A palaeoecological study of a late Holocene section from "Het Ilperveld", western Netherlands. Review of Palaeobotany and Palynology 36, 95-163.

Bennett, K., 1996. Determination of the number of zones in a biostratigraphical sequence. New Phytologist 132, 155-170.

Bennett, K.D., 2008. psimpoll and pscomb Programs for Plotting and Analysis, Version 4.27 (accessed March 2, 2014). http:// www.chrono.qub.ac.uk/psimpoll/psimpoll.html.

Blackwell, M., 2011. The fungi: 1, 2, 3 ... 5.1 million species? American Journal of Botany 98, 426-438.

Bronk Ramsey, C., Scott, M., van der Plicht, H., 2013. Calibration for archaeological and environmental terrestrial samples in the time range 26-50 ka cal BP. Radiocarbon 55, 2021-2027.

Bush, M., Silman, M.R., Urrego, D.H., 2004. 48,000 years of climate and forest change in a biodiversity hotspot. Science 303, 827-829.

Campbell, J.F.E., Fletcher, W.J., Hughes, P.D., Shuttleworth, E.L., 2016. A comparison of pollen extraction methods confirms densemedia separation as a reliable method of pollen preparation. Journal of Quaternary Science 31, 631-640.

Cárdenas, M.L., Gosling, W.D., Pennington, R.T., Poole, I., Sherlock, S.C., Mothes, P., 2014. Forests of the tropical eastern Andean flank during the middle Pleistocene. Palaeogeography, Palaeoclimatology, Palaeoecology 393, 76-89.

Colinvaux, P.A., Bush, M.B., Steinitz-Kannan, M., Miller, M.C., 1997. Glacial and postglacial pollen records from the Ecuadorian Andes and Amazon. Quaternary Research 48, 69-78.

Colinvaux, P.A., de Oliveira, P.E., Patiño, J.E.M., 1999. Amazon Pollen Manual and Atlas. Harwood Academic, Amsterdam.

Coltorti, M., Ollier, C.D., 2000. Geomorphic and tectonic evolution of the Ecuadorian Andes. Geomorphology 32, 1-19.

Connell, J.H., 1978. Diversity in tropical rain forests and coral reefs. Science 199, 1302-1310.

Cook, K.H., 2009. South American climate variability and change: remote and regional forcing processes. In Vimeaux, F., Sylvestre, F., Khodri, M. (Eds.), Past Climate Variability in South America and Surrounding Regions. Springer, Dordrecht, the Netherlands, pp. 193-212.

Cugny, C., Mazier, F., Galop, D., 2010. Modern and fossil nonpollen palynomorphs from the Basque mountains (western Pyrenees, France): the use of coprophilous fungi to reconstruct pastoral activity. Vegetation History and Archaeobotany 19, 391-408.

Davis, O.K., 1987. Spores of the dung fungus Sporormiella: increased abundance in historic sediments and before Pleistocene megafaunal extinction. Quaternary Research 28, 290-294.

Davis, O.K., Shafer, D.S., 2006. Sporormiella fungal spores, a palynological means of detecting herbivore density. Palaeogeography, Palaeoclimatology, Palaeoecology 237, 40-50.

Faegri, K., Iversen, J., 1989. Textbook of Pollen Analysis. 4th ed. Blackburn Press, Caldwell, NJ. 
Flantua, S.G.A., Hooghiemstra, H., Grimm, E.C., Behling, H., Bush, M.B., González-Arango, C., Gosling, W.D., et al., 2015. Updated site compilation of the Latin American Pollen Database. Review of Palaeobotany and Palynology 223, 104-115.

Galeas, R., Guevara, J.E., 2012. Sistema de clasificación de los Ecosistemas del Ecuador Continental. Subsecretaría de Patrimonio Natural, Quito, Ecuador.

Gelorini, V., Verbeken, A., van Geel, B., Cocquyt, C., Verschuren, D., 2011. Modern non-pollen palynomorphs from East African lake sediments. Review of Palaeobotany and Palynology 164, 143-173.

Gentry, A.H., 1988. Changes in plant community diversity and floristic composition on environmental and geographical gradients. Annals of the Missouri Botanical Garden 75, 1-34.

Gentry, A.H., 1995. Patterns of diversity and floristic composition in Neotropical montane forests. In Churchill, S.P., Balslev, H., Forero, E., Luteyn, J.L. (Eds.), Biodiversity and Conservation of Neotropical Montane Forests. New York Botanical Garden, New York, pp. 103-126.

Gill, J.L., McLauchlan, K.K., Skibbe, A.M., Goring, S., Zirbel, C.R., Williams, J.W., 2013. Linking abundances of the dung fungus Sporormiella to the density of bison: implications for assessing grazing by megaherbivores in palaeorecords. Journal of Ecology 101, 1125-1136.

Gill, J.L., Williams, J.W., Jackson, S.T., Lininger, K.B., Robinson, G.S., 2009. Pleistocene megafaunal collapse, novel plant communities, and enhanced fire regimes in North America. Science 326, 1100-1103.

González-Carranza, Z., Hooghiemstra, H., Vélez, M.I., 2012. Major altitudinal shifts in Andean vegetation on the Amazonian flank show temporary loss of biota in the Holocene. Holocene 22, 1227-1241.

Grabandt, R., 1990. Presence and ecological range of some algae, Testacea and fungal remains in moss samples of Colombian páramo vegetation. Quaternary of South America and Antarctic Peninsula 8, 85-105.

Graham, A., 2009. The Andes: a geological overview from a biological perspective. Annals of the Missouri Botanical Garden 96, 371-385.

Graham, G.L., 1983. Changes in bat species diversity along an elevational gradient up the Peruvian Andes. Journal of Mammalogy 64, 559-571.

Hall, M.L., Samaniego, P., Le Pennec, J.L., Johnson, J.B., 2008. Ecuadorian Andes volcanism: a review of Late Pliocene to present activity. Journal of Volcanology and Geothermal Research 176, 1-6.

Harling, G., 1979. The vegetation types of Ecuador-a brief survey. In Larsen, K., Holm-Nielsen, L.B. (Eds.), Tropical Botany. Academic Press, London, pp. 165-174.

Hawksworth, D.L., 2012. Global species numbers of fungi: are tropical studies and molecular approaches contributing to a more robust estimate? Biodiversity and Conservation 21, 2425-2433.

Heiri, O., Lotter, A.F., Lemcke, G., 2001. Loss on ignition as a method for estimating organic and carbonate content in sediments: reproducibility and comparability of results. Journal of Paleolimnology 25, 101-110.

Hooghiemstra, H., 1984. Vegetational and climatic history of the high plain of Bogotá, Colombia: a continuous record of the last 3.5 million years. Dissertationes Botanicae 79, 1-138.

Hooghiemstra, H., van der Hammen, T., 1993. Late quaternary vegetation history and paleoecology of Laguna Pedro Palo (subandean forest belt, Eastern Cordillera, Colombia). Review of Palaeobotany and Palynology 77, 235-262.

Hooper, D.U., Bignell, D.E., Brown, V.K., Brussaard, L., Dangerfield, M.J., Wall, D.H., Wardle, D.A., et al., 2000. Interactions between aboveground and belowground biodiversity in terrestrial ecosystems: patterns, mechanisms, and feedbacks. BioScience 50, 1049-1061.

Hoorn, C., Wesselingh, F.P., ter Steege, H., Bermudez, M.A., Mora, A., Sevink, J., Sanmartín, I., et al., 2010. Amazonia through time: Andean uplift, climate change, landscape evolution, and biodiversity. Science 330, 927-931.

Innes, J., Blackford, J., Simmons, I., 2010. Woodland disturbance and possible land-use regimes during the Late Mesolithic in the English uplands: pollen, charcoal and non-pollen palynomorph evidence from Bluewath Beck, North York Moors, UK. Vegetation History and Archaeobotany 19, 439-452.

Jacobson, D.J., Dettman, J.R., Adams, R.I., Boesl, C., Sultana, S., Roenneberg, T., Merrow, M., et al., 2006. New findings of Neurospora in Europe and comparisons of diversity in temperate climates on continental scales. Mycologia 98, 550-559.

Jørgensen, P.M., León-Yánez, S., 1999. Catálogo de las plantas vasculares del Ecuador. Monographs in Systematic Botany from the Missouri Botanical Garden 75. Missouri Botanical Garden Press, St. Louis, MO.

Ju, Y.-M., Rogers, J.D., Hsieh, H.-M., Vasilyeva, L., 2004. Amphirosellinia gen. nov. and a new species of Entoleuca. Mycologia 96, 1393-1402.

Juggins, S., 2007. C2 Version 1.5 User Guide. Software for Ecological and Palaeoecological Data Analysis and Visualisation. Newcastle University, Newcastle upon Tyne, UK.

Juggins, S., Birks, H.J.B., 2012. Quantitative environmental reconstructions from biological data. In Birks, H.J.B., Lotter, A.F., Juggins, S., Smol, J.P. (Eds.), Tracking Environmental Change Using Lake Sediments: Data Handling and Numerical Techniques. Springer, Dordrecht, the Netherlands, pp. 431-494.

Killeen, T.J., Douglas, M., Consiglio, T., Jørgensen, P.M., Mejia, J., 2007. Dry spots and wet spots in the Andean hotspot. Journal of Biogeography 34, 1357-1373.

Kuhry, P., 1985. Transgression of a raised bog across a coversand ridge originally covered with an oak-lime forest: palaeoecological study of a middle Holocene local vegetational succession in the Amtsven (northwest Germany). Review of Palaeobotany and Palynology 44, 303-353.

Kuhry, P., 1988. A paleobotanical and palynological study of Holocene peat from the El Bosque mire, located in a volcanic area of the Cordillera Central of Colombia. Review of Palaeobotany and Palynology 55, 19-72.

Livingstone, D.A., 1955. A lightweight piston sampler for lake sediments. Ecology 36, 137-139.

López-Sáez, J.A., López-Merino, L., 2007. Coprophilous fungi as a source of information of anthropic activities during the Prehistory in the Amblés Valley (Ávila, Spain): the archaeopalynological record. Revista Española de Micropaleontología 39, 103-116.

López-Vila, J., Montoya, E., Canellas-Bolta, N., Rull, V., 2014. Modern non-pollen palynomorphs sedimentation along an elevational gradient in the south-central Pyrenees (southwestern Europe) as a tool for Holocene paleoecological reconstruction. Holocene 24, 327-345.

MacArthur, R.H., 1969. Patterns of communities in the tropics. Biological Journal of the Linnean Society 1, 19-30.

Matthews-Bird, F., Brooks, S.J., Holden, P.B., Montoya, E., Gosling, W.D., 2016a. Inferring late-Holocene climate in the 
Ecuadorian Andes using a chironomid-based temperature inference model. Climate of the Past 12, 1263-1280.

Matthews-Bird, F., Gosling, W.D., Coe, A.L., Bush, M., Mayle, F.E., Axford, Y., Brooks, S.J., 2016b. Environmental controls on the distribution and diversity of lentic Chironomidae (Insecta: Diptera) across an altitudinal gradient in tropical South America. Ecology and Evolution 6, 91-112.

Montoya, E., Rull, V., van Geel, B., 2010. Non-pollen palynomorphs from surface sediments along an altitudinal transect of the Venezuelan Andes. Palaeogeography, Palaeoclimatology, Palaeoecology 297, 169-183.

Montoya, E., Rull, V., Vegas-Vilarrúbia, T., 2012. Non-pollen palynomorph studies in the Neotropics: the case of Venezuela. Review of Palaeobotany and Palynology 186, 102-130.

Moore, P.D., Webb, J.A., Collinson, M.E., 1991. Pollen Analysis. Blackwell Scientific, Oxford, UK.

Moscol-Olivera, M., Duivenvoorden, J.F., Hooghiemstra, H., 2009. Pollen rain and pollen representation across a forest-páramo ecotone in northern Ecuador. Review of Palaeobotany and Palynology 157, 285-300.

Myers, N., Mittermeier, R.A., Mittermeier, C.G., da Fonseca, G.A. B., Kent, J., 2000. Biodiversity hotspots for conservation priorities. Nature 403, 853-858.

Neill, D.A., 1999aGeology. In Jørgensen, P.M., León-Yánez, S. (Eds.), Catalogue of the Vascular Plants of Ecuador. Missouri Botanical Garden Press, St. Louis, MO, pp. 5-7.

Neill, D.A., 1999bVegetation. In Jørgensen, P.M., León-Yánez, S. (Eds.), Catalogue of the Vascular Plants of Ecuador. Missouri Botanical Garden Press, St. Louis, MO, pp. 13-25.

Neill, D.A., Jørgensen, P.M., 1999. Climates. In Jørgensen, P.M., León-Yánez, S. (Eds.), Catalogue of the Vascular Plants of Ecuador. Missouri Botanical Garden Press, St. Louis, MO, pp. 8-13.

Neill, D.A., Palacios, W.A., 1997. Gran Sumaco and Upper Napo River region, Ecuador. In Davis, S.D., Heywood, V.H., HerreraMacBryde, O., Villa-Lobos, J., Hamilton, A.C. (Eds.), Centres of Plant Diversity: A Guide and Strategy for Their Conservation Vol. 3. The Americas. IUCN, Cambridge, UK, pp. 496-500.

Niemann, H., Behling, H., 2008. Late Quaternary vegetation, climate and fire dynamics inferred from the El Tiro record in the southeastern Ecuadorian Andes. Journal of Quaternary Science 23, 203-212.

Oksanen, J., Blanchet, F.G., Kindt, R., Legendre, P., Minchin, P.R., O’Hara, R.B., Simpson, G.L., et al., 2016. vegan: Community Ecology Package. Version 2.3-5 (accessed August 8, 2016). https://cran.r-project.org/web/packages/vegan/index.html.

Peay, K.G., Baraloto, C., Fine, P.V.A., 2013. Strong coupling of plant and fungal community structure across western Amazonian rainforests. ISME Journal 7, 1852-1861.

Rademaker, K., Hodgins, G., Moore, K., Zarrillo, S., Miller, C., Bromley, G.R.M., Leach, P., Reid, D.A., Álvarez, W.Y., Sandweiss, D.H., 2014. Paleoindian settlement of the highaltitude Peruvian Andes. Science 346, 466-469.

Raper, D., Bush, M., 2009. A test of Sporormiella representation as a predictor of megaherbivore presence and abundance. Quaternary Research 71, 490-496.

R Development Core Team. 2015. R: A Language and Environment for Statistical Computing. R Foundation for Statistical Computing, Vienna, Austria.

Reimer, P.J., Bard, E., Bayliss, A., Beck, J.W., Blackwell, P.G., Bronk Ramsey, C., Buck, C.E., et al., 2013. IntCal13 and
Marine13 radiocarbon age calibration curves $0-50,000$ years cal BP. Radiocarbon 55, 1869-1887.

Rull, V., 2006. A high mountain pollen-altitude calibration set for palaeoclimatic use in the tropical Andes. Holocene 16, 105-117.

Rull, V., López-Sáez, J.A., Vegas-Vilarrúbia, T., 2008. Contribution of non-pollen palynomorphs to the paleolimnological study of a high-altitude Andean lake (Laguna Verde Alta, Venezuela). Journal of Paleolimnology 40, 399-411.

Rull, V., Vegas-Vilarrúbia, T., 1998. Palynomorphs other than pollen and fern spores in glacial sediments from the Venezuelan Andes. Preliminary assessment on their potential paleoecological value. Boletín de la Sociedad Venezolana de Geólogos 23, 5-27.

Rull, V., Vegas-Vilarrúbia, T., 1999. Surface palynology of a small coastal basin from Venezuela and potential paleoecological applications. Micropaleontology 45, 365-393.

Sierra, R., 1999. Propuesta preliminar de un sistema de clasificación de vegetación para el Ecuador continental. Proyecto INEFAN/GEF-BIRF y EcoCiencia, Quito, Ecuador.

Stern, M.J., 1995. Vegetation reorganisation on earthquaketriggered landslide sites in the Ecuadorian Andes. In: Churchill, S.P., Balslev, H., Forrero, E., Luteyn, J.L. (Ed.), Biodiversity and Conservation of Neotropical Montane Forests: Proceedings of the Neotropical Montane Forest Biodiversity and Conservation Symposium, the New York Botanical Garden, 21-26 June 1993. New York Botanical Garden Press, New York, p. 93.

Stevens, G.C., 1989. The latitudinal gradient in geographical range: how so many species coexist in the tropics. American Naturalist 133, 240-256.

Stockmarr, J., 1971. Tablets with spores used in absolute pollen analysis. Pollen et Spores 16, 615-621.

Tedersoo, L., Bahram, M., Põlme, S., Kõljalg, U., Yorou, N.S., Wijesundera, R., Ruiz, L.V., et al., 2014. Global diversity and geography of soil fungi. Science 346. 1256688. http://dx.doi.org/ 10.1126/science.1256688.

Terborgh, J., 1977. Bird species diversity on an Andean elevational gradient. Ecology 58, 1007-1019.

ter Braak, C.J.F., 1986. Canonical correspondence analysis: a new eigenvector technique for multivariate direct gradient analysis. Ecology 67, 1167-1179.

Urrego, D.H., Silman, M.R., Bush, M.B., 2005. The Last Glacial Maximum: stability and change in a western Amazonian cloud forest. Journal of Quaternary Science 20, 693-701.

Valencia, R., Cerón, C., Palacios, W.P., Sierra, R., 1999. Las formaciones naturales de la sierra del Ecuador. In: Sierra, R.M. (Ed.), Propuesta Preliminar de Un Sistema de Clasificación de Vegetación Para El Ecuador Continental. Proyecto INEFAN/GEF-GIRF y EcoCiencia, Quito, Ecuador, pp. 82-111.

van Geel, B., 1972. Palynology of a section from the raised peat bog 'Wietmarscher Moor', with special reference to fungal remains. Acta Botanica Neerlandica 21, 261-284.

van Geel, B., 1976. Fossil spores of Zygnemataceae in ditches of a pre-historic settlement in Hoogkarspel (the Netherlands). Review of Palaeobotany and Palynology 22, 337-344.

van Geel, B., 1978. A palaeoecological study of Holocene peat bog sections in Germany and the Netherlands, based on the analysis of pollen, spores and macro- and microscopic remains of fungi, algae, cormophytes and animals. Review of Palaeobotany and Palynology 25, 1-120.

van Geel, B., Andersen, S.T., 1988. Fossil ascopores of the parasitic fungus Ustulina deusta in Eemian deposits in Denmark. Review of Palaeobotany and Palynology 56, 89-93. 
van Geel, B., Aptroot, A., 2006. Fossil ascomycetes in Quaternary deposits. Nova Hedwigia 82, 313-329.

van Geel, B., Aptroot, A., Baittinger, C., Birks, H.H., Bull, I.D., Cross, H.B., Evershed, R.P., et al., 2008. The ecological implications of a Yakutian mammoth's last meal. Quaternary Research 69, 361-376.

van Geel, B., Bohncke, S.J.P., Dee, H., 1981. A palaeoecological study of an upper late glacial and Holocene sequence from "De Borchert", the Netherlands. Review of Palaeobotany and Palynology 31, 367-448.

van Geel, B., Buurman, J., Brinkkemper, O., Schelvis, J., Aptroot, A., van Reenen, G., Hakbijl, T., 2003. Environmental reconstruction of a Roman Period settlement site in Uitgeest (the Netherlands), with special reference to coprophilous fungi. Journal of Archaeological Science 30, 873-883.

van Geel, B., Coope, G.R., van Der Hammen, T., 1989. Palaeoecology and stratigraphy of the lateglacial type section at Usselo (the Netherlands). Review of Palaeobotany and Palyno$\log y$ 60, 25-129.

van Geel, B., Engels, S., Martin-Puertas, C., Brauer, A., 2013. Ascospores of the parasitic fungus Kretzschmaria deusta as rainstorm indicators during a late Holocene beech-forest phase around lake Meerfelder Maar, Germany. Journal of Paleolimnology 50, 33-40.

van Geel, B., Gelorini, V., Lyaruu, A., Aptroot, A., Rucina, S., Marchant, R., Damsté, J.S.S., Verschuren, D., 2011a. Diversity and ecology of tropical African fungal spores from a 25,000-year palaeoenvironmental record in southeastern Kenya. Review of Palaeobotany and Palynology 164, 174-190.

van Geel, B., Guthrie, R.D., Altmann, J.G., Broekens, P., Bull, I.D., Gill, F.L., Jansen, B., Nieman, A.M., Gravendeel, B., 2011b. Mycological evidence of coprophagy from the feces of an Alaskan Late Glacial mammoth. Quaternary Science Reviews 30, 2289-2303.

van Geel, B., Hallewas, D.P., Pals, J.P., 1983. A late Holocene deposit under the Westfriese Zeedijk near Enkhuizen (Prov. of
Noord-Holland, the Netherlands): palaeoecological and archaeological aspects. Review of Palaeobotany and Palynology 38, 269-335.

van Smeerdijk, D.G., 1989. A palaeoecological and chemical study of a peat profile from the Assendelver Polder (the Netherlands). Review of Palaeobotany and Palynology 58, 231-288.

Vera, R., 2013. Geology of Ecuador: An Introduction to the Unique Geology of Ecuador. Gráficas Iberia, Quito, Ecuador.

Vuille, M., Bradley, R.S., Keimig, F., 2000. Interannual climate variability in the Central Andes and its relation to tropical Pacific and Atlantic forcing. Journal of Geophysical Research: Atmospheres 105, 12447-12460.

Wallace, A.R., 1878. Tropical Nature and Other Essays. Macmillan, New York.

Webster, G.L., 1995. The panorama of Neotropical cloud forests. In: Churchill, S.P., Balslev, H., Forero, E., Luteyn, J.L. (Eds.), Biodiversity and Conservation of Neotropical Montane Forests. New York Botanical Garden, New York, pp. 53-77.

Weng, C., Bush, M.B., Silman, M.R., 2004. An Analysis of Modern Pollen Rain on an Elevational Gradient in Southern Peru. Journal of Tropical Ecology 20, 113-124.

Whitlock, C., Larsen, C., 2001. Charcoal as a fire proxy. In: Smol, J.P., Birks, H.J.B., Last, W.M. (Eds.), Tracking Environmental Change Using Lake Sediment Vol. 3. Terrestrial, Algal, and Siliceous Indicators. Kluwer Academic, Dordrecht, the Netherlands, pp. 75-97.

Williams, J.J., Gosling, W.D., Coe, A.L., Brooks, S.J., Gulliver, P., 2011. Four thousand years of environmental change and human activity in the Cochabamba Basin, Bolivia. Quaternary Research $76,58-68$.

Wilmshurst, J.M., McGlone, M.S., 2005. Origin of pollen and spores in surface lake sediments: comparison of modern palynomorph assemblages in moss cushions, surface soils and surface lake sediments. Review of Palaeobotany and Palynology $136,1-15$. 